\title{
Making Connections: A conference approach to developing transformative environmental and sustainability education within initial teacher education
}

\author{
Nicola Walshe ${ }^{1}$, Victoria Tait ${ }^{2}$ \\ ${ }^{1}$ Faculty of Health, Social Care and Education, Anglia Ruskin University, Cambridge, \\ UK. ORCID ID: 0000-0003-2123-4853 \\ ${ }^{2}$ Global Sustainability Institute, Anglia Ruskin University, Cambridge, UK
}

nicola.walshe@anglia.ac.uk

\section{Notes on contributors}

Nicola Walshe is Head of the School of Education and Social Care at Anglia Ruskin

University. Prior to this, she gained a PhD in glaciology and worked as Head of Geography in three secondary schools in the UK before going on to teach and lead the Geography PGCE course at Cambridge University. Nicola's current research interests include students' understandings of sustainability, the pedagogy of environmental and sustainability education, and curriculum and pedagogy within teacher education more broadly.

Victoria Tait is Education for Sustainability coordinator at the Global Sustainability Institute, Anglia Ruskin University. Her role is to ensure that sustainability is embedded across all courses at Anglia Ruskin in line with the University's Academic Regulations. Prior to this Victoria worked at SEEd, a Sustainability and Environmental Education charity, at the time one of only two UK institutions to be a member of the UNESCO Global Action Programme on Education for Sustainable Development. 


\title{
Making Connections: A conference approach to developing transformative environmental and sustainability education within initial teacher education
}

\begin{abstract}
Children today face significant challenges in response to living in a globalised world and the predicted environmental threats to the planet. However, implementing environmental and sustainability education (ESE) within schools can be complex and is often ignored within initial teacher education (ITE). In response, this project aimed to evaluate pedagogies for developing transformative learning for ESE within the context of university-based ITE. We ran a conference for trainee teachers informed by critical, participatory and arts-based pedagogic approaches. Alongside this, we undertook an interpretive case study, collecting data through questionnaires, focus groups and in-conference spoken reflection. Findings suggest trainee teachers gained a more nuanced understanding of the value and nature of ESE, as well as more affective and informed engagement with it, across the conference. Implications for ESE within ITE focus around the potential of pedagogies which provide affective experiences, in particular participatory and arts-based pedagogical approaches, for inspiring and empowering trainee teachers to enter into schools and develop their own ESE practice as classroom teachers.
\end{abstract}

Keywords: environmental and sustainability education (ESE); initial teacher education (ITE); transformative learning; conference; arts-based pedagogies 


\section{Introduction}

Children today face significant challenges in response to living in a globalised world and the impact of environmental threats to the planet, for example climate change, rising inequalities, and food and water security (World Economic Forum, 2017); as such, there is an increasing need for schools to have a global rather than merely local perspective and to cultivate in students a critical sense of environmental and social responsibility (Pe'er, Goldman, and Yavetz 2007). Environmental and Sustainability Education (ESE) is frequently promoted as a route to achieving this as it has the potential to empower learners to 'develop the necessary knowledge, understanding, skills, values, capabilities and dispositions to respond to the complex socio-ecological issues of the 21st century' (Australian Research Institute for Environment and Sustainability, 2009, 3). There is significant global interest in embedding sustainability within education (e.g. Bürgener and Barth 2018; Holm et al. 2016; UN 2015) and, consequently, it has been argued extensively that ESE should be better integrated into Initial Teacher Education (ITE) programmes (e.g. Cutter-Mackenzie and Tilbury 2002; Clarke and McPhie 2016; Ferreira, Ryan, and Tilbury 2007; UNESCO 2014). However, embedding what Evans et al. $(2017,407)$ describe as a 'complex combination of interdisciplinary knowledge, understanding, skills, values and dispositions' into the curriculum is a challenge for schools, teachers and initial teacher educators and there persists a clear lack of pedagogical consensus as to how to teach either about or for ESE in school or Higher Education (HE) contexts (e.g. Cotton et al. 2007). Perhaps as a result, the extent to which ESE has been integrated into ITE within HE institutions is variable, with many criticising the lack of progress in this area (e.g. Esa 2010; Falkenberg and Babiuk 2014; Kapitulčinová et al. 2015). This is of particular importance when evidence suggests that the quality of ESE has a significant influence 
on trainee teachers' ability and inclination to teach it (e.g. Miles, Harrison, and CutterMackenzie 2006).

In response, this paper explores pedagogies for teaching ESE within ITE, particularly in the context of a Primary Education Studies undergraduate degree course in the UK. Specifically, it aims to add to the relatively small research base surrounding ESE pedagogies and their theoretical underpinning, considering the transformative impact of ESE pedagogy and practice on trainee teacher understandings of the nature and value of ESE within the context of a one-day conference event. While the term pedagogy is difficult to define, it typically refers to the 'art' or 'science' of teaching and is understood to encompass not just what the teacher does, but the process by which any learning takes place (MacDonald, 2002). It is broadly acknowledged that pedagogies embed socially constructed and culturally specific processes and practices (e.g. Kirk et al., 1996; Luke and Luke, 1994); as such, they can reflect particular ideological positions and be underpinned by one or more pedagogical approaches, such as behaviourist (e.g. Skinner, 1957), constructivist (e.g. Piaget, 1960), social constructivist (e.g. Vygotsky, 1978) or liberationist (e.g. Freire, 1996) approaches. While these complexities will be reflected on throughout this paper, we define pedagogy at its simplest as a conscious activity by one person designed to enhance learning in another.

\section{Trainee teacher perceptions of ESE: a rationale for initial teacher education}

It can be argued that trainee teachers develop their own curricula and pedagogies so that they are congruent with their existing understandings, perspectives and ideologies (Curtner-Smith 2007; Miles, Harrison, and Cutter-Mackenzie 2006). While this may not always be the case and others suggest that a process of socialisation inducts trainees into a particular set of values within their initial teacher education (e.g. Ball and Goodson 1985; Brooks 2016), it seems likely that trainee teachers' ability to mainstream ESE in 
schools is influenced by their understanding of sustainability (Firth and Winter 2007). Yet the majority of studies on ITE students' understandings of sustainability raise concerns over their lack of knowledge on sustainability issues; in those cases where it is present, these understandings are frequently dominated by the environmental dimension of sustainability (e.g. Birdsall 2013; Dyment and Hill 2015; Kilinic and Aydin 2013; Tomas and Mills 2011). In relation to ESE, Evans et al. (2012) found that trainee teachers who were exposed to some form of sustainability learning presented a generally unproblematic view of ESE; they argue this lack of criticality to be the result of the technocratic worldview which presents environmental problems as being free from values or tensions (after Robottom 1987), suggesting ITE should plan to develop in trainee teachers a more nuanced understanding of ESE. Beyond a need for criticality, Cutter-Mackenzie and Tilbury (2002) found that 'perspective teachers do not have the pedagogical content knowledge to effectively teach environmental education in primary schools' (30) and 'university based teacher education reinforces attitudes by its emphasis on .... the downplaying of [sustainability] knowledge' (17). While many researchers argue that knowledge of sustainability alone may not necessarily lead to action on important issues, nor to the effective teaching of ESE in classrooms (e.g. Cutter-Mackenzie and Smith 2003; Cutter-Mackenzie and Tilbury 2002), others suggest that a sound knowledge of sustainability issues - in addition to the necessary pedagogical skills, values and attitudes - would better support trainee teacher confidence and readiness to enact ESE in schools (Kennelly, Taylor, and Maxwell 2008; Symons 2008). Jensen (2002) supports this point, with the further caveat that knowledge relating to environmental education should be rethought from an 'action perspective' to effect change in behaviour. The wider project within which the research reported in this paper sits aimed to address this need, focusing on developing both 
content (or disciplinary) knowledge of trainee teachers, as well as their understanding of associated pedagogies; the focus of this paper is the latter, specifically ESE pedagogies.

\section{ESE approaches and pedagogies within ITE}

Teaching for ESE has been described as a wicked problem with multiple complex, context-based and uncontrollable variables that affect learning (Evans 2016); perhaps as a result, there remains a lack of consensus as to what pedagogical approaches for ESE should be (Tomasa, Girgentib, and Jackson 2017). Sterling (2014) suggests that there are three forms of ESE pedagogies: transmissive, transactional and transformative; as learners move from one to the next, they experience a shift towards a deeper form of engagement. A challenge for university-based ITE is that the teacher-centred pedagogy commonly associated with HE reflects a more transmissive pedagogy which has been argued as being little use for ESE (e.g. Bosselmann 2001; Cotton and Winter 2010). In contrast, ESE pedagogies are inherently student-centred and reflect a more socioconstructivist understanding of learning with a shift in focus from content to participatory, situated and collaborative approaches which empower students to become co-constructors of their learning (Bedi and Germein 2016; Christie and Miller 2015).

Within these constructivist and social constructivist learning paradigms, ESE scholars generally agree that there is, therefore, a need for participatory, place-based, enquiry-based pedagogies (e.g. Bosselmann 2001; Cotton et al. 2009; Sterling 2008) which are inherently student-centred, modelling activities that trainee teachers can themselves use in schools (Cotton and Winter 2010; Littledyke and Manolas 2010). These include a range of strategies, such as: role-plays and simulations to provide the opportunity for students to gain an in-depth understanding of other people's perspectives (e.g. Aleixandre and Gayoso 1996; Oulton et al. 2004); group discussions and debates which encourage students to gather information and develop arguments 
(e.g. Corney and Reid 2007; Cotton and Winter 2010); place-based outdoor experiences, including field investigations (e.g. Paige, Lloyd, and Chartres 2008; Whitehouse 2008), which can help develop critical thinking skills essential to understanding the complexity of sustainability (Scott and Gough 2003), as well as influencing student emotions through experiential activities (e.g. Burke and CutterMackenzie 2010; Sivek 2002); and problem-solving activities (Jenkins 1999/2000) and problem-based learning (Brundiers and Wiek 2013; Thomas 2009) which promote the conceptual and practical aspects of sustainability literacy (Cotton and Winter, 2010) and frequently involve decision-making about local case studies (Cotton et al. 2009). Although the consensus is clearly with post-positivist approaches to education which are both active and student-centred, there is also an assertion by some (e.g. Firth and Winter 2007; Westwood 2008) that some direct teaching methods, such as lecturing, are essential for the early stages of learning new information.

While this list of pedagogies presented is comprehensive, Evans et al. (2017) suggest that there has been limited critical reflection upon the effectiveness of each activity, particularly how they develop trainee teachers' ESE knowledge, values or subsequent pedagogical practice. This highlights the need for research on the effectiveness of ESE pedagogies in ITE, inclusive of critical reflection and evaluation, particularly theorising different pedagogical approaches in the light of educational theory (Dillon 2003).

\section{Transformative learning as an approach to ESE}

Sterling (2010/11) argues that in order to develop truly effective ESE pedagogies educators should look to learning theory; in particular, he draws attention to transformative learning theory. Transformative learning is a potentially important aspect of ESE as it encourages learners to move beyond simple acquisition of knowledge 'to a 
level of holism and depth capable of changing ways they understand, experience or conceptualise their world' (Evans 2016, 447); as such, it signifies a change in worldview for the learner. More specifically, Mezirow $(2000,7)$ defines transformative learning as a process whereby 'we transform our taken-for-granted frames of reference to make them more inclusive, discriminating, open, [changeable], and reflective so that they may generate beliefs and opinions that will prove more true or justified to guide action'. In this way, Mezirow's suggestion is that transformative learning involves a shift in consciousness which affects our deeper level of understanding and, perhaps more importantly for ESE, a change in our behaviour.

With this in mind, Sterling (2010/11) refers to work originally posited by Bateson (1972) but adapted variously by authors such as Argyris and Schön (1996) and Ison and Russell (2000), to distinguish three orders of learning and change. First-order learning refers to doing 'more of the same', perhaps in a slightly more efficient way, without examining the values that inform that action. Sterling (2010/11) suggests that, because of its content-led nature, the majority of learning within formal education settings such as schools and HE is first-order learning, taught through transmissive pedagogies with little critical reflection to challenge the beliefs of the learners. Secondorder learning refers to significant changes in thinking based on the examination of assumptions and values through meta-cognitive processes. This type of learning can be more challenging as it involves critical reflection of knowledge, values and beliefs; for this reason, it is considered to be more permanent (Sterling, 2010/11). Finally, according to Bateson (1972), third-order learning is epistemic, in that it causes us to profoundly challenge and reconstruct our deeper held beliefs and values. Blake, Sterling and Goodson (2013) note that for some, transformative learning would facilitate a shift from first-order to second-order learning, whereas for others it necessarily equates to the 
change in world-view depicted by third-order learning. For both, what is significant is that it often involves resistance on the part of the learner because it 'poses a significant challenge to existing beliefs and ideas, reconstruction of meaning, discomfort and difficulty' (Sterling 2010/11, 25).

While this preference for third order learning might seem desirable within the context of ESE, there are criticisms of this approach (Taylor and Cranton 2013); one of particular note is the assumption that there is inherent good in transformation (e.g. Baptiste 2008). By definition, transformative learning is seen to be good such that we should move towards new frames of reference which are 'better than others because they are more likely to generate beliefs and opinions that will prove more true or justified to guide action' (Mezirow 2003, 58-59). Critics argue that this definition is culturally-bound and based on humanist and constructivist assumptions that reflect Western values and beliefs that anyone can achieve anything if only they work hard enough to overcome whatever barriers they face (Taylor and Cranton 2013). As such, transformative learning can be seen as a colonial construct which does not appropriately reflect the socio-cultural and historical contexts in which learning is taking place. While Mezirow (2012) himself asserts the importance of transformative learning, not indoctrination, it is important for educators reflect on the purpose and mechanism of ESE with a view to critical engagement with, rather than purely promotion of, sustainable development (e.g. Vare and Scott 2007).

While Sterling (2010/11) suggests transformative learning is difficult for teachers to facilitate, there is some discussion within the literature as to what learning approaches or pedagogical practice might be transformational (e.g. Ukpokodu 2009). Mezirow (1991) originally saw three constructs as being central: critical reflection for deeper understanding and action, dialogue with others (after Vygotsky 1978), and 
experience (e.g. Dewey 1933). In this way, transformational learning approaches align well not only with experiential and dialogic pedagogies of ESE as already described, but with critical pedagogies which, according to Wink (2000), generate a questioning frame of mind, a reflective approach to our actions and the actions of others, and a commitment to do something.

With this in mind, we designed an event aimed at embedding ESE into ITE, enabling trainee teachers to critically reflect on both the processes used and the knowledge gained, with the aim of facilitating transformative learning. Given restrictions in access to standard curriculum time, a one-day, immersive conference was undertaken, drawing on suggestions by Weissner et al. (2008) and Elliot (2005) to develop learning through a conference in which knowledge construction, active learning and critical reflection are key. This represents an accommodation response to the challenge of sustainability, wherein learning about sustainability is 'bolted on' to a programme while other parts of the curriculum remain unchanged. Although this approach is not believed to have as transformative an effect as embedded, long-term strategies (e.g. Dawe, Jucker, and Martin 2005; Wals and Jickling 2002), Sterling $(2004,60)$ acknowledges that singular events can be useful as they can 'open the door to deeper change'.

Alongside the conference event, we undertook a research project seeking to privilege students' voice by eliciting their views on their conference experience to help evaluate ESE pedagogical approaches. Research questions informing the project design are as follows:

(1) How do undergraduate trainee teachers' understandings of the value and nature of ESE develop across a conference event? 
(2) To what extent do pedagogies within the conference support transformative learning for ESE?

(3) What are the implications for pedagogy and practice within initial teacher education?

This aim of this particular paper is to examine pedagogies for ESE; as such, we will use responses from research question 1 to provide context for a more full and considered analysis of questions 2 and 3.

\section{Research Design}

Teaching for transformation through ESE pedagogies embodies a social constructivist epistemology through which learners construct their own meaning by building on their previous knowledge and experience through engagement in student-centred, active and collaborative activities (Vygotsky 1978). This accepts the fact that trainee teachers attend HE with 'personal foundations of experience' (Evans 2016, 448), which include previous experiences of learning situations, as well as their knowledge, assumptions, values and conceptual frameworks (e.g. Boud 2011; Littledyke and Manolas 2010); these inevitably affect their engagement with both information they receive and pedagogies they experience. As such, this study was framed as an interpretive, multiple methods case study underpinned by a social constructivist epistemology in recognition of the social construction of student understandings of the nature and value of ESE and their engagement with it. We adopted a critical ontological perspective (e.g. Kincheloe, 2003; Meyer 2011) with the view that reality is socially constructed by people in society within which 'complex power relations ... evolve from a constant dialectical interplay of structure and agency over time' (Wigger and Horn 2017, 38). Within the context of this study, the intention was that this approach would facilitate students' deep reflection 
on their own experiences, ideas and beliefs across the conference and associated research.

\section{Context of the Study}

This research was undertaken with participants of the Environmental and Sustainability Education: Making Connections day conference at a university in England; these comprised predominantly 75 first and second year students from a BA (Hons) Primary Education Studies undergraduate course at that university, although there were also 15 postgraduate trainee teachers (both primary and secondary geography) from a nearby university and eight members of staff. The Primary Education Studies undergraduate course is a three-year theory-based programme developing students' content knowledge and pedagogical content knowledge (Shulman 1986) alongside broader ideas of child development and the sociology and philosophy of education. The student population comprises a combination of school leavers and mature aged students from a wide variety of backgrounds, educational and life experiences. Postgraduate courses involve 120 days of school-based placement experience alongside this theoretical knowledge. All conference participants were asked to complete questionnaires for the study, and we asked for volunteers from within this to be involved in more detailed research involving focus groups and verbal reflections; ten volunteered, eight undergraduate students, one postgraduate (primary) trainee teacher and one university lecturer - all but one female. We recognise that this was a self-selecting sample of students and that the results of this aspect of the study are not, therefore, generalisable to the rest of the cohort.

\section{Methodology and Methods}

For the purposes of this study we adopted Stake's (1994) instrumental case study approach through which we explored one bounded case (the conference). This enabled 
us to gain a rich picture of participants' developing understandings of the nature and purpose of ESE, whilst at the same time allowing us to make what Bassey (1999) terms ‘fuzzy generalisations' about ESE pedagogies, general statements with built-in uncertainty which are possible in case study research without reducing its trustworthiness (Lincoln and Guba 1985).

\section{Questionnaires}

All conference participants were asked to anonymously complete an online qualitative questionnaire before and after the conference. The initial questionnaire explored participants' pre-existing understandings of the nature and value of ESE; within it, they were asked to provide a definition of ESE and to comment on its importance, as well as to describe any school-based ESE practice they have seen. The questionnaire following the conference asked participants to redefine ESE and comment again on its importance; this second questionnaire also included questions to elicit participant feelings about each of the conference sessions and how these affected their perceptions of sustainability. Response rates were 43\% (42/98) for the first and 27\% (26/98) for the second questionnaires; while this low response rate is not unusual for questionnaires (e.g. Baruch and Holtom 2008), it did limit the quantity of data we had available to analyse for post-conference reflections.

\section{Spoken reflections}

The ten volunteer participants were given voice recording equipment to provide spoken reflection on their experiences across the day. Keats (2009) suggests that spoken texts can be recorded as anecdotal field-based notes with more likelihood of open and honest reflection than in interviews or focus groups. While we used this as a methodologically novel approach to exploring participant experience, allowing us to elicit immediate and 
free responses to the conference sessions, these reflections tended to lack the depth and criticality developed in focus groups, sometimes appearing rushed (between sessions) or providing only superficial responses. As such, it was the combination of data from spoken reflections, focus groups and questionnaire data that was more valuable.

\section{Focus Groups}

Two focus groups were undertaken, one with six and another with four volunteer participants, immediately following the conference to elicit their responses to the day, discuss their learning and explore their perceptions of the value of ESE.

\section{Data Analysis}

Focus group and spoken reflections were transcribed following which analysis of transcripts and questionnaire responses was undertaken through manual coding in two ways to elicit different information from the data:

(1) We used inductive, open coding to explore trainees' understandings of the value and nature of ESE (research question 1). Through this recursive process of classifying, juxtaposing and reporting (e.g. Dey 1993), a set of categories emerged from the data (see Table 1).

(2) We created a set of a priori codes using Sterling's (2010/11) three levels of learning to analyse the extent to which conference pedagogies supported transformative learning for ESE (research question 2; see Table 2). Text which indicated simply the addition of new knowledge were coded as first order learning. Phrases which suggested a student had reflected either on their own practice or their pre-existing knowledge were assigned to second order learning. Finally, where students reflected on and appeared to shift (at least in that moment) a prior belief system this was categorised as third order learning. While 
we acknowledge the criticisms levelled at this approach and accept that it is difficult to evidence third order learning, this gave us a broad framework through which to discuss changes in trainee understanding of ESE across the conference.

Coding was an iterative process undertaken a number of times to increase its trustworthiness; analysis was undertaken blind as to whether pre-conference or postconference to reduce potential bias in categories emerging.

\section{INSERT TABLE 1 HERE}

INSERT TABLE 2 HERE

In undertaking the research, we followed the BERA Ethical Guidelines (BERA 2018) and obtained ethical approval from [Authors' university] prior to the commencement of the project.

\section{Operationalising ESE pedagogies: the Conference}

The conference comprised a range of keynote lectures and participatory workshops (Table 3). Although lectures can be criticised as being passive forms of positivist education which emphasise the acquisition of objective and factual information (Littledyke and Manolas 2010), they can be used to support more constructivist, learner-centred approaches (Christie et al. 2013). In this instance, keynote lectures within the conference were given by 'expert' speakers, providing a range of perspectives on the value and context of ESE in practice (as suggested by Alvarez and Rogers [2006], and Blake, Sterling, and Goodson [2013]); participants were then able to reflect on this throughout the more participatory workshops of the day. 
The profound, epistemic change of third-order transformative learning is more likely to be achieved through a diverse range of student-centred, active and critical pedagogies (Slavich and Zimbardo 2012); as such, beyond the keynote lectures (with a focus on the cognitive dimension of learning), we incorporated a series of workshops that encouraged students to engage with different issues (affective dimension) and question their own values (existential dimension). The aim was to address Hicks' suggestion that transformative learning should involve 'three awakenings - of the mind, the heart and the soul' $(2002,102)$. Huckle (2004) further argues that ESE is transformative if it is critical and empowering; as such, the conference was underpinned by critical pedagogical approaches which place increased emphasis on developing critical and reflective capacities in learners (e.g. Reid 2002). For example, in the workshop Loving Nature through your Feet: using walk and talk methods to connect with place the facilitator used a critical pedagogy of place, taking participants outside to deepen empathetic connections and provide knowledge about their local environment that is grounded in firsthand, shared experience (Gruenewald 2003). Participants were asked to complete pre-conference reading for workshops, enabling the hosts to provide a range of initial content knowledge which was built on within their session. All workshops then incorporated reflection and action (praxis) allowing 'teachers' and 'students' to explore connections between issues and the environmental, social, political and economic implications, together with subtexts related to power interests (Freire 1996; Giroux 2011).

\section{INSERT TABLE 3 HERE}

\section{Results and Analysis}

This section firstly considers the extent to which ESE pedagogies within the conference 
supported transformative learning for ESE (research question 2), and then takes a thematic approach to a discussion of the wider implications of the study for pedagogy and practice within teacher education (research question 3).

\section{To what extent do pedagogies support transformative learning for ESE?}

Our second research question explored how participant responses provided evidence for transformative learning across the conference, using Sterling's (2010/2011) hierarchy of learning as a framework for analysis (Table 2). Of the coded responses, $27 \%$ were identified as evidence for first order change (basic increases in cognition), $61 \%$ as evidence for second order change (metacognitive reflection resulting in examining and changing assumptions), and $11 \%$ as potential evidence for moving towards third order change (epistemic change reflecting deeper, transformative learning).

All second questionnaire responses evidenced at least some new levels of knowledge (first order); this was evident in particular through student definitions of sustainability. For example, pre-conference definitions focused on the environment (e.g. Dyment and Hill 2015; Kagawa 2007), such as 'minimising the damage we cause the environment through using renewable resources'; whereas after the conference, whilst the number of references to the environment remained relatively high, there was increased reference to social and economic dimensions of sustainability, such as 'global citizenship and appreciation of cultural diversity and of arts and creativity'. This illustrates increases in basic cognition and first order learning and yet is of significance as Howell and Allen (2017) suggest that social justice is an equally powerful means of engaging people in sustainability-related issues, such as biophilia; in this way even basic knowledge has the potential to become transformative.

Beyond first order learning, there was evidence that most participants also 
reflected on their knowledge and developed new perspectives on issues across the conference (second order learning: 27 mentions). For example, within initial definitions of sustainability, participants portrayed an instrumentalist, utilitarian conception of nature (e.g. Walshe 2017), as illustrated through vocabulary such as protect and use; one participant stated 'sustainability is maintaining a level of resources for future use'. After the conference, references to the environment persisted through vocabulary of protection and stewardship, for example 'the ways in which we can preserve the environment by being more environmentally friendly'. However, there was evidence that five students were beginning to rethink this dialectic of humans as a part of or apart from nature (Lee et al. 2018); for example, one participant defined 'the balance of a species with its environment', the reference here to a species possibly suggesting a movement towards an understanding of ourselves as relational, entangled becomingswith (Taylor 2017).

Cranton (1996) argues that the objective of transformative learning is to revise old assumptions and ways of interpreting experience; within this study, we suggest that second order learning was also evident through participants' metacognitive reflection in which they examined and changed their assumptions of the nature of ESE. For example, in the pre-conference questionnaires, in alignment with their environmentally-focused understandings of sustainability, student descriptions of ESE pedagogies were limited; for example, 'planting trees to try to get children to grow more at home' and 'teaching children to recycle'. After the conference students gave a broader definition, challenging these traditional perceptions of ESE; for example, one talked of 'developing the awe and wonder of life', another that 'imagination and creativity are essential components' of ESE. Further, some students began to reconceptualise 'the outdoors' beyond being a place for gardening; for example, one reflected 
A lot of the time ... people think that EE is about going to green areas or being in the countryside with trips organised to different forests and woodlands, [but] even in a big city it's a huge environmental ecosystem and there's a lot you can get from this outdoor environment.

In a similar vein, another student considered on the city as nature, reflecting Alexandra's (2017) imaginings of the city as nature and the nature of the city:

Cities have incredible ecosystems ... that is the only access to nature that a lot of children have. We should be celebrating that ... but you have to change how you think about places to be able to see that.

As such, students appeared to be changing the way they thought about nature, thereby evidencing second order learning.

Sterling and Baines (2002) suggest that third order learning can be a lengthy process which takes place over time as mental models undergo radical change; for this reason, it is likely to be difficult to develop across one conference event. However, we suggest that there was some evidence of deeper, more transformative (third order) learning within participant responses. One area where this was evident was through understanding what sustainability is, particularly the importance of social or economic dimensions. For example, one student commented 'I was quite surprised because when I first thought about sustainability I always linked it to the environment ... but then we started talking about social justice and I hadn't thought about it in that way before'; another 'it made you realise that we can survive the basic needs but without social justice it's not really a sustainable environment or world'. In this way, it seems they had started to experience a shift in understanding (Mezirow 1997), or altered frame of reference (Moore 2005), through critical reflection about the nature of sustainability. Although this represents relatively small change, it is through this critical reflection of behaviours and assumptions that, Moore (2005, 82-83) argues, we can "relocate 
understandings, change worldviews, and create transformative learning experiences".

Some participants also articulated the challenge and discomfort they experienced throughout the conference, something which has been suggested can facilitate more transformative learning (e.g. Moore, 2005); for example 'I struggled with that ... for me the spirituality part was something that was tough, it was hard to listen to' and 'those nitty gritty questions about the quality of education and you know what do we actually need to do? How do we need to teach children?'. Finally, some participants talked bluntly about the intention to transform their behaviour, for example one reflected 'I didn't really feel any passion towards sustainability however [now I feel] like I want to make a change to my own habits'. As such, while this is more difficult to evidence within the shorter timeframe of one conference, participants appeared to begin to exhibit some aspects of deeper, transformative learning. We suggest further research taking a more longitudinal approach is needed to fully explore both the nature of transformative learning, and any longer term changes to participants' thinking and subsequent impact on practice.

\section{What are the wider implications for ESE pedagogy and practice within initial teacher education?}

There are four themes emerging from the data which have significant implications for ESE pedagogy and practice within initial teacher education. The first relates to the conference format for $\boldsymbol{E S E}$; despite being a 'one-off' approach to engaging trainee teachers with ESE, the use of a conference appears to have been significant both for the way it afforded more inspirational experiences for participants, but also by providing a space for thinking more deeply and holistically about issues of sustainability. Without engaging, inspirational practice that empowers trainee teachers to go into school and 
teach ESE, this study suggests ESE within HE will not be transformative - trainees will not go and teach it with any meaning, particularly in a curriculum where they have to choose to make space for it. One participant commented '[I have] changed because there's more to being a primary school teacher than delivering a curriculum ... to inspire children'. Jickling $(2017,28)$ suggests that educational experiences which are 'held, felt and disruptive' are the basis for transformative learning; as such, it is a complex process, by its nature involving thoughts and feelings (Baumgartner 2001), without which learners would not begin critical reflection (Taylor 2000, 291). Through the conference, the combination of prolific external speakers, innovative workshops and the coming together of a community of learners internal and external to the university (with staff participating alongside students) generated a sense that participants were involved in something special and worthwhile. This contributed to creating an inspirational atmosphere around the day, potentially allowing the conference to become a triggering event for transformative learning (Mezirow 1991).

Beyond inspiration, trainee teachers commented on the significance of the use of a conference for providing space for developing ideas and illustrating interconnections between ideas. For example, Helen noted 'Because you've got such a diversity of things on one day it made you think about them being connected a lot more ... There's kind of a separateness of doing it one week after the other [within a module]'. Elizabeth, a primary PGCE trainee from a neighbouring university, was able to reflect on this further as she has already attended discrete lectures by two of the keynote speakers:

We had [keynote lecturers 1 and 2] both come and speak to us at university ... but [the conference] was better because when we heard it before it was in the melee of loads of other lectures, whereas today because we have had the whole day all about sustainability ... I think that this will have much more impact on me. I remember hearing them the first time around and thinking this is great, but then I had to go to a maths seminar and think about using 
place value counters or something, I wasn't able to assimilate it and process it in a way that I think I was able to today.

As such, while there seems to be a consensus that ESE is best when embedded within ITE courses or modules to provide extensive opportunities to develop values which embrace ESE pedagogy and practice (e.g. Evans, Whitehouse, and Hickey 2012), this study highlights the value of a conference as an opportunity to immerse trainee teachers in critical, experiential pedagogies. While a conference is not a pedagogy in and of itself, encapsulating ESE within such an event appeared to provide trainees the space within which to fully consider and develop their understanding of the value and nature of ESE per se.

The second theme relates to empowerment of trainee teachers; the challenge and, for some, discomfort experienced during the conference appeared to play a transformative role, thereby empowering them both as individuals and educators. For some, this was experienced through the more traditional lectures; for example one participant stated 'it was really really wonderful ... I really loved hearing what he had to say ... I love love loved it and I'd love to look into it more' (Lecture 1). For others, it was the workshops; for example, one participant reflected on initial discomfort they felt within the drama activity: 'I think that it broke down a lot of barriers for me ... it wasn't something I would normally do ... but I can see how children would enjoy and understand being able to do something like this' (Workshop 4). In deconstructing their perceptions of what ESE is, participants were also encouraged to be braver in their approaches to it, using a critical pedagogical approach to encourage risk-taking; for example, referring to creative adventuring in Workshop 1, one suggested 'we need to have courage to go and do it, not hold back just go for it and if it doesn't work out then try something new'. This had an emancipatory effect; for example, one participant 
reflected on the walking activities (Workshop 5): 'it's quite empowering to think I could do that or we could do that in schools and classrooms...I've always had the opinion that one person is not going to make much of a difference, but ... the negative image of me saying that "oh, one person is not going to change this" is actually wrong.' The transformative nature of the conference appears to have substituted these feelings of apathy and powerlessness with those that 'one ... indeed can make a difference' (Wals and deJong 1997, 127). For one of the postgraduate trainee teachers, this was immediately impacting her practice:

I'm going to teach English next week ... I'm teaching setting and they're reading the Lion the Witch and the Wardrobe as their stimulus, where Edmond is walking through the woods to get to the White Witch's palace and actually I was thinking why don't I just take them outside? Why don't we think about going and creating their own setting? We've got this massive field which no-one ever uses ... that's going to require me to be quite brave.

As such, it is not simply about knowing more about ESE, but engaging with it differently through more affective, creative pedagogies (Nguyen and Larsen 2015), such as drama, art and walking, which appears to empower trainee teachers to want to take risks within the classroom (Jenkins 1999/2000).

The third theme relates more specifically to the importance of affective pedagogies for supporting ESE, particularly through arts-based approaches. StevensLong, Schapiro and McClintock (2012) stress the significance of emotions in transformative learning; the workshops using arts-based pedagogical approaches, such as Developing Children's Connectedness to Nature using Artists in Wild Places (Workshop 1) and Using Drama to Support ESE (Workshop 4), appeared to facilitate a more emancipatory learning experience for students with the development of skills of critical reflection and emotional sensitivity described by Rovengo and Kirk (1995). Participants reflected on this, for example one commented that the creative workshops 
'were about taking education that step further'. Another reflected more specifically on the drama activities (Workshop 4): 'It broke down a lot of barriers and a lot of things you wouldn't necessarily normally do but I can see how relevant it is for children, how much children would enjoy and understand being able to do something like this.'. As such, the creative approaches appeared to be seen as novel ways of learning about ESE within school contexts, providing more affective experiences in which, one participant commented, 'children are given a voice to lead the way'. This supports a body of literature arguing the case for the role of arts both in shaping pro-environmental behaviour (e.g. Curtis, Reid and Reeve 2014), and supporting ESE within a range of school and early years contexts (e.g. Clark and Button 2010; Ward 2013). The arts have been shown not only to support cognitive processes, but also to facilitate development of an emotional connection to learning (Wilson 2010) within ESE. This study supports this, suggesting that arts-based pedagogies, such as art and drama-based activities, have potential to support affective domains of learning within ESE in ITE, thereby engaging and enabling trainee teachers to enact these within their own practice.

The final theme is the apparent tension between a focus on knowledge and pedagogy within ESE. Previous research suggests that simply transmitting information about sustainability issues makes little difference to students' understanding of or engagement with ESE (e.g. Christie and Miller 2015); instead, it has been argued that HE must develop agency and engagement through critical and constructivist approaches that build upon existing knowledge to facilitate transformative learning (e.g. Huckle 2004; Janse van Rensburg et al. 2000). However, within this study participants highlighted the significance of knowledge gained across the conference for empowering them to teach ESE. For example, one stated 'it deepened my personal understanding to be able to reflect on my own practices', and another commented 'it gave me different 
ways to look at the problems facing us and how to begin to tackle this area in schools'. Moreover, while Sterling (2014) suggests that transmissive ways of teaching ESE, such as lectures, can be less transformative, these were highly rated by conference participants; for example, one reflected 'I thought [Lecture 1] was really, really wonderful' and another 'I found this session so engaging and exciting ... it gave such a clear message of the necessity to connect children to nature'. There are two potential implications of this finding. Firstly, relating to the importance of knowledge, we suggest that rather than being a barrier to engagement, knowledge transmission is an important precursor to transformative learning; providing students with knowledge helps make ESE meaningful to them, as well as giving them agency to develop their own ESE practice. This is not simply knowledge which is co-created by students from interpretations and reinterpretations in light of new experiences, as suggested by constructivist paradigm, but epistemic knowledge about a real, objective and knowable world. This brings us to the second implication concerning the nature of the knowledge: what constitutes important, or 'powerful' (after Young 2008) ESE knowledge for trainee teachers? Jensen (2002) argues the case for action-oriented knowledge within ESE containing four dimensions: knowledge about the effects of problems; knowledge about the causes; knowledge about strategies for change; and knowledge about alternative possibilities and visions (including those from wider cultures and contexts). However, what constitutes powerful knowledge around these four dimensions remains uncertain, and further research is needed to clarify what this might look like to ensure pedagogical approaches that sufficiently encourage learners to question, problematise and debate that knowledge are then developed.

\section{Conclusions}

While many initial teacher educators report their pedagogical practice for ESE is well- 
grounded in the educational literature, Evans et al. (2017) suggest that a lack of critique limits the development of an in-depth understanding of ESE pedagogies within ITE. This small study has gone some way to address this, highlighting the potential of using critical, participatory and arts-based pedagogical approaches within the body of a conference for developing trainee teachers' understandings of the value and nature of ESE. In particular, results suggest the importance of providing affective experiences which are inspirational for empowering trainee teachers and facilitating transformative learning (Mezirow 1991). Both the content and pedagogical content knowledge becomes more powerful when it is inspirational; this is key for empowering and motivating trainee teachers to enter into schools and develop their own ESE practice as classroom teachers. Encapsulating these affective experiences within the body of a conference event appeared to magnify the impact of individual pedagogical approaches on both trainees' learning and engagement, providing a potentially more meaningful experience of ESE. However, this creates a challenge: while the one-off conference appeared to become a trigger event for transformative ESE learning, literature suggests that more sustained and embedded opportunities for learning may be better placed to develop greater bodies of knowledge across a period of time within the HE context (e.g. Corney 2006; Dawe et al. 2005). As such, further research is needed to consider how approaches can be combined to provide an inspirational trigger event for transformative learning, followed by an embedded programme which supports trainee teachers in a critical, participatory way, thereby sustaining engagement with ESE beyond the HE context and into the school classroom. 


\section{Acknowledgements}

We would like to thank Anglia Ruskin University for the Global Sustainability Institute 'Be the Change' Grant and Faculty Course Leader Funding which funded the conference. A huge thank you also goes to the conference presenters for making the keynotes and workshops so informative and inspirational, as well as to the participants for the enthusiasm with which they approached the day. We are also particularly grateful for the constructive comments that the anonymous reviewers provided on earlier drafts of this article.

\section{Disclosure statement}

No potential conflict of interest was reported by the authors. 


\section{References}

Alexandra, J. 2017. "The city as nature and the nature of the city - climate adaptation using living infrastructure: governance and integration challenges." Australasian Journal of Water Resources 21 (2): 63-76.

Aleixandre, M.P.J., and I.G.-R. Gayoso. 1996. “An approach to introducing environmental education into the science methods course in teacher education." Environmental Education Research 2 (1): 27-39.

Alvarez, A., and J. Rogers. 2006. "Going 'out there': learning about sustainability in place." International Journal of Sustainability in Higher Education 7 (2): 176188.

Argyris, C. and D. Schön. 1996. Organisational Learning II. New York: Addison Wesley.

Australian Research Institute for Environment and Sustainability [ARIES]. 2009. Education for Sustainability: The role of education in engaging and equipping people for change. Accessed 15 August 2018. http://aries.mq.edu.au/publications/aries/efs_brochure.

Ball, S., and I. Goodson. 1985. Teachers' Lives and Careers. London: Falmer Press.

Baptiste, I.M. 2008. "Wages of niceness: The folly and futility of educators who strive not to impose." New Horizons in Adult Education and Human Resource Development 22 (2): 6-28.

Baruch, Y. and B.C. Holtom. 2008. "Survey response rate levels and trends in organizational research." Human Relations 61(8): 1139-1160.

Bassey, M. 1999. Case Study Research in Educational Settings. Buckingham: Open University Press.

Bateson, G. 1972. Steps to an Ecology of Mind. Chandler: San Francisco, CA, USA.

Baumgartner, L.M. 2001. “An Update on Transformational Learning.” Special Issue: The New Update on Adult Learning Theory 89: 15-24.

Bedi, G. and S. Germein. 2016. "Simply good teaching: transformation and change through education for sustainability." Australian Journal of Environmental Education 32 (1): 124-133.

Birdsall, S. 2013. 'Measuring student teachers' understandings and self-awareness of sustainability." Environmental Education Research 20 (6): 814-835. doi: 13504622.2013833594. 
Blake, J., S. Sterling, and I. Goodson. 2013. "Transformative Learning for a Sustainable Future: An Exploration of Pedagogies for Change at an Alternative College." Sustainability 5: 5347-5372.

Bosselmann, K. 2001. University and Sustainability: Compatible Agendas?" Educational Philosophy and Theory 33 (2): 167-186.

Boud, D. 2011. "Experience as the Base for Learning.". In Higher Education Research and Development Anthology, edited by P. Kandlbinder, and T. Peseta, 25-36. Milperra, NSW: HERDSA.

Brooks, C. 2016. Teacher Subject Identity in Professional Practice: Teaching with a professional compass. London: Routledge.

British Educational Research Association (BERA). 2018. Ethical Guidelines for Educational Research. London: BERA.

Brundiers, K., and A. Wiek. 2013. "Do we teach what we preach? An international comparison of problem- and project-based learning courses in sustainability." Sustainability 5: 1725-1746.

Bürgener, L. and M. Barth. 2018. Sustainability competencies in teacher education: making teacher education count in everyday school practice. Journal of Cleaner Production 174: 821-826.

Burke, G., and A. Cutter-Mackenzie. 2010. "What's there, what if, what then, and what can we do? An immersive and embodied experience of environment and place through children's literature." Environmental Education Research 16 (3): 311330.

Christie, B. and K. Miller. 2015. “Academics' opinions and practices of education for sustainable development: reflections on a nation-wide, mixed-methods, multidisciplinary study." in Routledge Handbook of Higher Education for Sustainable Development, edited by M. Barth, G. Michelsen, M. Rieckmann and I. Thomas. Routledge: London.

Christie, B. A., K. K. Miller, R. Cooke, and J. G. White. 2013. "Environmental Sustainability in Higher Education: How Do Academics Teach?” Environmental Education Research 19 (3): 385-414.

Clarke, D.A.G. and J. Mcphie. 2016. "From places to paths: learning for sustainability, teacher education and a philosophy of becoming." Environmental Education Research 22 (7): 1002-1024. 
Clark, B. and C. Button. 2010. "Sustainability transdisciplinary education model: interface of arts, science, and community (STEM)." International Journal of Sustainability in Higher Education 12 (1): 41-54.

Corney, G. 2006. "Education for sustainable development: An empirical study of the tensions and challenges faced by Geography student teachers." International Research in Geographical and Environmental Education 15 (3): 224-40.

Corney, G., and A. Reid. 2007. 'Student teachers' learning about subject matter and pedagogy in education for sustainable development." Environmental Education Research 13 (1): 33-54. doi: 10.1080/13504620601122632.

Cotton, D. R. E., M. F. Warren, O. Maiboroda, and I. Bailey. 2007. "Sustainable Development, Higher Education and Pedagogy: A Study of Lecturers' Beliefs and Attitudes." Environmental Education Research 13 (5): 579-597.

Cotton, D., I. Bailey, M. Warren and S. Bissell. 2009. "Revolutions and second-best solutions: education for sustainable development in higher education." Studies in Higher Education 34 (7): 719-733. https://doi.org/10.1080/03075070802641552

Cotton, D. and J. Winter. 2010. “ 'It's not just bits of paper and light bulbs': A review of sustainability pedagogies and their potential for use in Higher Education". in Sustainability Education: Perspectives and Practice across Higher Education, edited by P. Jones, D. Selby and S. Sterling, 39-54. London: Earthscan.

Cranton, P. 1996. "Types of group learning." New Directions for Adult and Continuing Education 71: 25-32.

Curtis, D.J., N. Reid, and I. Reeve. 2014. "Towards ecological sustainability: observations on the role of the arts." Surveys and Perspectives Integrating Environment and Society 7 (1). https://journals.openedition.org/sapiens/1655

Curtner-Smith, M. 2007. "The impact of a critically oriented physical education teacher education course on perservice classroom teachers." Journal of Teaching in Physical Education 26: 35-56.

Cutter-Mackenzie, A. and R. Smith. 2003. 'Ecological literacy: the 'missing paradigm' in education (part one)." Environmental Education Research 9 (4): 497-524.

Cutter-Mackenzie, A. and D. Tilbury. 2002. "Meeting commitments for a sustainable future: Environmental education in pre-service teacher education". In Reconceptualising learning in the knowledge society, edited by B. Knight, 1734. Flaxton: Post Pressed. 
Dawe, G., R. Jucker, and S. Martin. 2005. Sustainable development in higher education: Current practice and future developments. A report for the Higher Education Academy. New York, United Kingdom: Higher Education Academy.

Dey, I. 1993. Qualitative Data Analysis: A User-friendly Guide for Social Scientists. Abingdon: Routledge.

Dewey, J. 1933. Experience and education. New York: Macmillan Publishing Co.

Dillon, J. 2003. “On learners and learning in environmental education: Missing theories, ignored communities." Environmental Education Research 9 (2): 215-226. doi: $10.1080 / 13504620303480$.

Dyment, J.E., and R. Hill. 2015. "You mean I have to teach sustainability too? Initial teacher education students' perspectives on the sustainability cross-curriculum priority.” Australian Journal of Teacher Education 40 (3): 21-35.

Elliot, C. 2005. "AHRD conference 2005: An opportunity to review our learning." Human Resource Development International 8 (4): 503-8

Esa, N. 2010. "Environmental knowledge, attitude and practices of student teachers." International Research in Geographical and Environmental Education 19 (1): 39-50.

Evans, N., H. Whitehouse, and R. Hickey. 2012. "Pre-service Teachers' Conceptions of Education for Sustainability.” Australian Journal of Teacher Education 37 (7): $1-12$.

Evans, N. 2016. "Implementing education for sustainability in Higher Education through student-centred pedagogies." In: Routledge Handbook of Higher Education for Sustainable Development, edited by M. Barth, G. Michelsen, M. Rieckmann and I. Thomas, 445-461. Abingdon: Routledge.

Evans, N., R.B. Stevenson, M. Lasen, J. Ferreira, and J. Davis. 2017. “Approaches to embedding sustainability in teacher education: A synthesis of the literature." Teaching and Teacher Education 63: 405-417.

Falkenberg, T., and G. Babiuk. 2014. "The status of education for sustainability in initial teacher education programmes: A Canadian case study.” International Journal of Sustainability in Higher Education 15 (4): 418-430.

Ferreira, J.-A., L. Ryan., and D. Tilbury. 2007. "Mainstreaming education for sustainable development in initial teacher education in Australia: A review of existing professional development models." Journal of Education for Teaching 33 (2): 225-239. 
Firth, R., and C. Winter. 2007. "Constructing education for sustainable development: The secondary school geography curriculum and initial teacher training." Environmental Education Research 13 (5): 599-619.

Freire, P. 1996. Pedagogy of the Oppressed. Penguin: London.

Giroux, H. 2011. On critical pedagogy. London: Bloomsbury.

Gruenewald, D. A. 2003. "The best of both worlds: A critical pedagogy of place." Environmental Education Research 14 (3): 308-324.

Hicks, D. 2002. Lessons for the Future: the missing dimension in education, Futures and Education Series. London: RoutledgeFalmer.

Holm, T., K. Sammalisto, S. Caeiro, M. Rieckmann, J. Dlouhá, T. Wright, K. Ceulemans, J. Benayas, and R. Lozano. 2016. Call for papers: Developing sustainability into a golden thread throughout all levels of education. Journal of Cleaner Production.

Howell, R.A., and S. Allen. 2017. "People and planet: Values, motivations and formative influences of individuals acting to mitigate climate change." Environmental Values 26 (2): 131-155.

Huckle, J. 2004. "Critical realism - a philosophical framework for higher education for sustainability." In Higher Education and the Challenge of Sustainability, edited by P. Corcoran and A. Wals, 33-46, Kluwer.

Ison, R. and D. Russell. 2000. Agricultural Extension and Rural Development: breaking out of traditions, a second-order systems perspective. Cambridge: Cambridge University Press.

Janse van Rensburg, E., H. Lotz, D. Du Toit, K. Mhoney, and C. Oliver. 2000. Learning for Sustainability: an environmental education professional development case study informing education policy and practice. Johannesburg, Learning for Sustainability Project.

Jenkins, K. 1999/2000. "Listening to secondary pre-service teachers: Implications for teacher education." Australian Journal of Environmental Education 15 (16): 4556.

Jensen, B.B. 2002. "Knowledge, Action and Pro-environmental Behaviour." Environmental Education Research 8 (3): 325-334.

Jickling, B. 2017. "Education revisited: creating educational experiences that are held, felt, and disruptive". In Post-Sustainability and Environmental Education: Remaking Education for the Future, edited by B. Jickling and S. Sterling, 15-30, 
Palgrave Studies in Education and the Environment, doi 10.1007/978-3-31951322-5_2

Kagawa, F. 2007. "Dissonance in Students' Perceptions of Sustainable Development and Sustainability." International Journal of Sustainability in Higher Education, 8 (3): 317-338.

Kapitulčinová, D., J. Dlouhá, A. Ryan, A. Barton, J. Dlouhý, M. Mader, et al. 2015. Leading practice publication: Professional development of university educators on Education for Sustainable Development in European countries. Charles University in Prague. Accessed 15 August 2018. http://en.unesco.org/esdrepo/660/.

Keats, P.A. 2009. "Multiple text analysis in narrative research: visual, written, and spoken stories of experience." Qualitative Research 9 (2): 181-195.

Kennelly, J., N. Taylor, and T.W. Maxwell. 2008. “Addressing the challenge of preparing Australian pre-service primary teachers in environmental education: An evaluation of a dedicated unit." Journal of Education for Sustainable Development 2 (2): 141-156.

Kincheloe, J. L. 2003. “Critical ontology: Visions of selfhood and curriculum.” Journal of Curriculum Theorizing, 19 (1): 47-64.

Kirk, D., J. Nauright, S. Hanrahan, D. Macdonald, and I. Jobling. 1996. The Sociocultural Foundations of Human Movement. Melbourne: Macmillan.

Lee, E., N. Walshe, R. Sapsed R., and J. Holland. 2018. “Artists as emplaced pedagogues: how does thinking about children's nature relations influence pedagogy?” In Springer International Handbooks of Education. Research Handbook on ChildhoodNature: Assemblages of Childhood and Nature Research, edited by A. Cutter-Mackenzie, K. Malone and E. Barratt Hacking. https://link.springer.com/referenceworkentry/10.1007/978-3-319-51949-4_78-1

Lincoln, Y.S., and E.G. Guba. 1985. "But is it rigorous? Trustworthiness and authenticity in naturalistic inquiry." In Naturalistic evaluation, edited by D.D. Williams. San Francisco: Jossey-Bass.

Littledyke, M. and E. Manolas. 2010. "Ideology, Epistemology and Pedagogy: Barriers and Drivers to Education for Sustainability in Science Education.” Journal of Baltic Science Education 9 (4): 285-301. 
Luke, A. and C. Luke. 1994. "Pedagogy" in The Encyclopedia of Language and Linguistics. Edited by R.E. Asher and J.M. Simpson. Tarrytown, New York: Elsevier Science/Pergamon. 566-568.

Maniates, M. 2002. "Of knowledge and power" in Encountering Global Environmental Politics: Teaching, Learning, and Empowering Knowledge, edited by M. Maniates. Rowman and Littlefield Publishers, Inc., Lanham, MD

MacDonald, D. 2002. "Critical Pedagogy: What it might look like and why does it matter?” In: The Sociology of Sport and Physical Education. Edited by A. Laker. London: Routledge. 167-189.

Meyer, E.J. 2011. “Critical Ontology and Teacher Agency” In Key Works in Critical Pedagogy. Bold Visions in Educational Research, vol 32, edited by K. Hayes, S.R. Steinberg, and K. Tobin. SensePublishers 219-226.

Mezirow, J. 1991. Transformative Dimensions of Adult Learning. San Francisco: Jossey-Bass.

Mezirow, J. 1997. "Transformative learning: Theory to practice.” New Directions for Adult and Continuing Education 7: 5-12.

Mezirow, J. 2000. Learning as Transformation: critical perspectives on a theory in progress. San Francisco: Jossey Bass.

Mezirow, J. 2003. “Transformative learning as discourse.” Journal of Transformative Education 1 (1): 58-63.

Mezirow, J. 2012. "Learning to think like an adult: Core concepts of transformative learning theory." In Handbook of Transformative Learning: Theory, research and practice, edited by E.W. Taylor and P. Cranton. San Francisco: Jossey Bass. 73-96.

Miles, R., L. Harrison, and A. Cutter-Mackenzie. 2006. “Teacher Education: A Diluted Environmental Education Experience.” Australian Journal of Environmental Education. 22 (1): 49-59.

Moore, J. 2005. "Is Higher Education Ready for Transformative Learning? A Question Explored in the Study of Sustainability." Journal of Transformative Education 3 (1): 76-91.

Nguyen, D.J. and J.B. Larson. 2015. "Don't Forget About the Body: Exploring the Curricular Possibilities of Embodied Pedagogy." Innovation in Higher Education 40: 331-344. 
Nolet, V. 2009. "Preparing sustainability-literate teachers." Teachers College Record 111 (2): 409-442.

Oulton, C., J. Dillon, and M. Grace. 004. "Reconceptualising the teaching of controversial issues.” International Journal of Science Education 26 (4): 411 423.

Paige, K., D. Lloyd, and M. Chartres. 2008. "Moving towards transdisciplinarity: An ecological sustainable focus for science and mathematics pre-service education in the primary/middle years." Asia-Pacific Journal of Teacher Education 36 (1): 19-33.

Pe'er, S., D. Goldman, and B. Yaveltz. 2007. "Environmental Literacy in Teacher Training: Attitudes, Knowledge, and Environmental Behavior of Beginning Students." Journal of Environmental Education 39 (1): 45-59.

Piaget, J. 1990. The child's conception of the world. New York: Littlefield Adams.

Reid, A. 2002. "Discussing the possibility of education for sustainable development." Environmental Education Research 8 (1): 73-79.

Robottom, I. (Ed.). 1987. Environmental education: Practice and possibility. Geelong, Victoria: Deakin University Press.

Rovengo, I. and Kirk, D. 1995. “Articulations and silences in socially critical work on physical education: toward a broader agenda." Quest 47, 447-474.

Scott, W.A.H. and S.R. Gough. 2003. Sustainable Development and Learning: Framing the Issues. RoutledgeFalmer: London, UK.

Shulman, L. 1986. Those who understand: Knowledge growth in teaching. Educational Researcher 15 (2): 4-14.

Sivek, D.J. 2002. "Environmental sensitivity among Wisconsin high school students." Environmental Education Research 8 (2): 155-170.

Skinner, B.F. 1957. Verbal Behavior. New York: Appleton-Century-Crofts.

Slavich, G.M. and P.G. Zimbado. 2012. "Transformational Teaching: Theoretical Underpinnings, Basic Principles, and core Methods." In E-xcellence in Teaching, edited by T. Zinn, B.K. Saville and J.E. Williams. Society for the Teaching of Psychology, Vol. 5, 55-9. http//teachpsych.org/ebooks/eit2005/index.php.

Stake, R. E. 1994. “Case studies.” In Handbook of qualitative research, edited by N. K. Denzin and Y. S. Lincoln, 236-247. Thousand Oaks, CA: Sage. 
Sterling, S. and J. Baines. 2002. A Review of Learning at Schumacher College, Dorchester: Bureau for Environmental Education and Training. Unpublished report to Schumacher College.

Sterling, S. 2004. "Higher Education, Sustainability, and the Role of Systematic

Learning." In Higher Education and the Challenge of Sustainability. Problems, Promise and Practice, edited by P. B. Corcoran and A. E. J. Wals, 49-70.

Dordrecht, Kluwer Academic Publishers.

Sterling, S. 2008. Sowing Seeds: How to Make Your Modules a Bit More Sustainability

Oriented: A Help Guide to Writing and Modifying Modules to Incorporate Sustainability Principles. Plymouth, Centre for Sustainable Futures, Plymouth University.

https://www.plymouth.ac.uk/uploads/production/document/path/2/2633/Sowing Seeds20June2008.pdf.

Sterling, S. 2010-11. "Transformative Learning and Sustainability: sketching the conceptual ground." Learning and Teaching in Higher Education 5, 17-33

Sterling, S. 2012. The Future Fit Framework: An Introductory Guide to Teaching and Learning for Sustainability in HE. York: The Higher Education Academy.

Sterling, S. 2014. "Separate Tracks or Real Synergy? Achieving a Closer Relationship between Education and SD, Post-2015." Journal of Education for Sustainable Development 8 (2): 89-112.

Stevens-Long., J., S.A. Schapiro, and C. McClintock. 2012. "Passionate scholars; transformative learning in doctoral education." Adult Education Quarterly 62 (2): 180-198.

Symons, G. 2008. Practice, Barriers and Enablers in ESD and EE: A Review of the Research. Shrewsbury: Council for Environmental Education.

Taylor, E.W., and P. Cranton. 2013. "A theory in progress? Issues in transformative learning theory." European journal for Research on the Education and Learning of Adults 4 (1): 33-47.

Taylor, E.W. 2000. “Analyzing Research on Transformative Learning Theory.” In Learning as Transformation: Critical Perspectives on a Theory in Progress, edited by J. Mezirow et al. San Francisco: Jossey-Bass.

Taylor, A. 2017. "Beyond stewardship: common world pedagogies for the Anthropocene.” Environmental Education Research 23 (10): 1448-1461. doi: 10.1080/13504622.2017.1325452. 
Thomas, I. 2009. "Critical Thinking, transformative learning, sustainable education, and problem-based learning in universities." Journal of Transformative Education 7: 245-264.

Tomas, L., and R. Mills. 2011. 'Pre-service teachers' understanding and concern for sustainability issues: implications for teacher education." In Proceedings of the Australian Teacher Educators' Association 2011 Conference: Valuing Teacher Education: Policy, Perspectives and Partnerships, 1-7, Melbourne, Australia, July 3-6, 2011.

Tomasa, L., S. Girgentib and C. Jackson. 2017. "Pre-service teachers' attitudes toward education for sustainability and its relevance to their learning: implications for pedagogical practice." Environmental Education Research 23 (3): 324-347. http://dx.doi.org/10.1080/13504622.2015.1109065

Ukpokodu, O. 2009. "The Practice of Transformative Pedagogy." Journal on Excellence in College Teaching 20 (2): 43-67.

UNESCO. 2014. Medium-Term Strategy 2014-21: Laying Foundations for Equitable Lifelong Learning for All. Hamburg: UNESCO Institute for Lifelong Learning. Vare, P., and W. Scott. 2007. "Learning for a Change: Exploring the Relationship Between Education and Sustainable Development." Journal of Education for Sustainable Development 1 (2): 191-198.

Vygotsky, L. 1978. Mind in Society: the development of higher psychological processes. Cambridge, MA: Harvard University Press.

Wals, A. and F. de Jong. 1997. "Community-based environmental education, school culture and lifelong learning." In Lifelong Learning and Environmental Education, edited by W. Leal Fihlo. Frankfurt: Peter Lang Verlag.

Wals, A.E.J. and B. Jickling. 2002. “"Sustainability” in higher education: From doublethink and newspeak to critical thinking and meaningful learning." International Journal of Sustainability in Higher Education 3 (3): 221-232. doi: 10.1108/14676370210434688.

Walshe, N. 2017. “An interdisciplinary approach to environmental and sustainability education: developing geography students' understandings of sustainable development using poetry." Environmental Education Research 23 (8): 11301149. doi: 10.1080/13504622.2016.1221887. 
Ward, K.S. 2013. "Creative Arts-Based Pedagogies in Early Childhood Education for Sustainability (EfS): Challenges and Possibilities.” Australian Journal of Environmental Education 29 (2): 165-181.

Westwood, P.S. 2008. What Teachers Need to Know about Teaching Methods. ACER Press: Victoria, Australia.

Whitehouse, H. 2008. “"EE in cyberspace, why not?” Teaching, learning and researching tertiary pre-service and in-service teacher environmental education online.” Australian Journal of Environmental Education 24 (2008): 11-21.

Wiessner, C.A., T. Hatcher, D. Chapman, and J. StorbergWalker. 2008 “Creating new learning at professional conferences: an innovative approach to conference learning, knowledge construction and programme evaluation.” 11 (4): 367-383.

Wigger, A., and L. Horn. 2017. "Taking Critical Ontology Seriously: Implications for Political Science Methodology.” In Handbook of Research Methods and Applications in Political Science, edited by H. Keman, and J. Woldendorp, 3853). Cheltenham, UK: Edward Elgar Publishing.

World Economic Forum. 2017. Global Shapers Survey. World Economic Forum. Accessed 20 September 2019.

http://shaperssurvey2017.org/static/data/WEF_GSC_Annual_Survey_2017.pdf

Wright, S. 2012. Children, meaning-making and the arts. Sydney, Australia: Pearson

Young, M. 2008. Bringing knowledge back in: From social constructivism to social realism in the sociology of education. London: Routledge. 